\title{
Information literacy: the backbone of curricular school reforms in Croatia
}

\author{
Jadranka Lasic-Lazic \\ Professor \\ Department of information science \\ Faculty of Philosophy, University of Zagreb \\ Croatia
}

Mihaela Banek-Zorica

Research and teaching assistant Department of information science Faculty of Philosophy, University of Zagreb

Croatia

The paper will examine how new information and educational environments are build in an EU candidate country, Croatia, and whether information literacy is an integral element of the launched strategies and reformal efforts. A crucial element for the intended transformations is the educational sector, which is thriving for curricula modifications, but also for reconceptualizations of pedagogical processes with a focus on student-centeredness and the quality of education. The authors will investigate information literacy perceptions in the Croatian school library environment, specifically in relation to computer literacy, and the actual current state of influence of libraries on the creation of constructivist classrooms.

\section{Introduction}

Changes in the educational philosophy and practice are a crucial roadmap on the way to the knowledge society. These changes include a greater focus on learning outcomes, inquiry-based learning, evidence-based practice and school accountability, informed decision making and self-directed learning (learning-to-learn), altogether causing transformations in the nature and role of the school librarian. Libraries have always been a part of the educational infrastructure, and the contemporary context strengthens this position. Libraries have fulfilled educational functions from the 
beginning of their existence, but today the philosophical foundation for this service has changed, encompassing transformations of content offered, the media used, the audience focused on and the overall relevance for the society. The result of the described shift is the globally known concept of information literacy. The current information literacy landscape shows great disparities due to the fact that information literacy is actually closely tied to a whole range of issues, e.g. the educational system, traditions in librarianship, the cultural background, the labour market and generally the wider political and social context, which causes significant differences between countries.

\section{School libraries, information literacy and contemporary educational reforms}

Educational systems are highly sensitive to social change; therefore the emergence of knowledge-based societies have had a deep impact on the world of learning. Since the new societies need multi-skilled workers capable of adapting to a rapidly changing external environment, the emphasis shifts toward empowering individuals to learn throughout their lives in an independent and self-directed manner, their preparation for critical thinking, creative problem-solving and decision-making, which create the foundation for intelligent existence in contemporary complex settings.

The described social constellation generated new educational values encompassing the movement from a content-orientation to a process-orientation in learning processes, shifts from a teacher-centred to learner-centred views of education, from memorization and reproduction to participation and construction, discovery and exploration.

Libraries as a part of the educational-informational infrastructure can make a unique and specific contribution in supporting the described $21^{\text {st }}$ century educational paradigms manifested in student-centred models by enabling users for lifelong learning. The new direction in educational and library policies is labelled information literacy and denotes the ability to recognize, locate, organize, evaluate and use effectively the needed information. In addition to this determination, the complementarities of information literacy with contemporary educational reforms are metaphorically described by many authors who refer to information literacy as a precondition for survival and success in an information/technology environment and for leading a productive, healthy and satisfying live in a democratic society (Bawden, 2001). Some authors name information literacy a "catalyst for educational change" (Bruce, 2002, p.1), describe it as a revolution in education (Breivik, 1999, p. 271), the key to lifelong learning (Špiranec, 2003) or as an enabler for bridging digital divides and for participation in the democratic environment (Prague Decleration, 2003). Information literacy is consequently incomparable with traditional user education since it reaches far beyond the library walls and implies engagement of the educational sector. How does it actually support the described educational reform efforts and how it transforms the essence of learning processes?

The correlation between information literacy and new models of learning is a strong one and derives from the contemporary complex and dynamically changing information universe where content is unfiltered and unorganized and the information 
flood is uncontrolled and overwhelming. Since the basic component of education is information, the new pedagogical paradigms are based on the premise of constant interactions with the present complex information environment, where the learner constructs knowledge rather than passively receives it. Information literacy presents a form of empowerment of the learner, who does not depend on the teacher when acquiring knowledge. He is involved in the discovery of knowledge and learns from interactions with available resources. Information literacy prepares learners to connect, interact and utilize this accessible wealth of information (Todd, 2001), not just in periods of compulsory schooling and under the supervision of a teacher as an authoritative knowledge resource but independently throughout their lives by strategically gathering, evaluating, synthesizing and presenting information.

For educational reforms to be applied in every day practice, it is important to recognize that the learning environment is larger than the school, that learning happens on the global information infrastructure and through interaction with information and that information literacy attributes like accessing, evaluating, and using information are integral to understanding content and crucial for learning success.

\section{The context of Croatia}

\section{Educational reforms in the Croatian school environment}

As a EU candidate country, Croatia devises clear strategies for progress towards the information society. A crucial element for the intended transformations is the educational sector, which is thriving for curricula modifications, but also for reconceptualisations of pedagogical processes with a focus on child/student-centeredness and the quality of education as precondition for the creation of a new information-age school. The problem of a technical information infrastructure was addressed very soon, highlighted in all public spheres and applied in all branches of economy, science and education areas. The essence of developments directed towards building a modern information society is captured in a program launched and approved by the Croatian government entiteled Croatia in the 21th century (Hrvatska u 21. stoljeću) ${ }^{1}$, which has produced different documents, e.g.. on education, informtion technology macroeconomy, science et.c. All of these documents take into account the requirements of the knowledgebased economy, the increasing importance of intellectual capital in the employing sector and the concept of lifelong learning. Different aims at transformation into e-Croatia are undertaken, e.g. the program Net into schools which has made Internet access available in all schools and was paralleled by the development of ICT skills among pupils and teachers.

\footnotetext{
${ }^{1}$ Hrvatska u 21. stoljeću. URL: http://www.hrvatska 21.hr/
} 
The latest document articulating and recommending educational reforms in primary and secondary school environments ${ }^{2}$ was launched in the year 2005 as the Croatian National Educational Standard (CNES). The new educational objectives set in Croatia correspond to the objectives that dominate the educational sector in the EU and are directed at building a knowledge-based society in which the school system is primarily intended to prepare pupils for lifelong learning. The Standard was generated as a result of the recognized problems of overloading pupils, inadequate teaching methods and insufficient monitoring and evaluation of the qauality of education. In it's essence, it acknowledges that it is important to relieve pupils from encyclopaedic content and direct them toward creativity, problem-solving abilities and lifelong learning.

The CNES as a strategic document also refers to the school library as an important factor in modernizing the educational process, stating that: "...by providing space, materials and an educational concept determined by the school librarian in cooperation with teachers and pupils the library plays an active role in the desired educational changes." (Guide, 2005, p. 17). Nevertheless, when it comes to defining the actual supportive role of school libraries in educational reforms, the Standard confines to computer literacy: «...by using modern technology, the library becomes an informative and stimulating educational, cultural and creative center. The school library is also an important factor in the development of computer literacy as the basis for lifelong learning". Information literacy is not identified as a potential area that could have a positive effect on teaching and learning. The lack of references to information literacy in this and other strategic documents mirrors the general national information and educational policy that are mainly directed towards the technical information infrastructure. Computer literacy alone does not guarantee preparedness for living in an information rich environment or lifelong learning. Although the dominance of technology and the development of skills to handle information and communication technology seems a logical step towards preparing citizens for living in contemporary societies, for seizing the benefits of the information age, people need a whole conglomerate of values, attitudes, skills, knowledge and perspectives directed towards enabling for critical thinking, self-directed learning and the responsible cosnsume of information - not only the technology but it's content - i.e they have to be information literate.

\section{The survey}

After identifying the lack of information literacy in educational policies, school reform efforts and information strategies in Croatia, a snapshot investigation was undertaken to determine information literacy perceptions among school librarians, specifically in relation to the predominating computer literacy concept. Further, the study was undertaken to give evidence on the actual current state of influence of libraries on the creation of constructivist classrooms and whether this particular profession has the potential of being the driving force for integrating information literacy into the launched strategies.

The aims of the study where:

\footnotetext{
${ }^{2}$ In Croatia, primary school consists of a total of 8 years. Upon the completion of 8 th grade, pupils advance to secondary school with the option of enrolling into either a four-year Grammar school (Gymnasium) or three/four year vocational school.
} 
- to determine whether and what types of education and training activities do school libraries in Croatia perform?

- to investigate the perception and awareness about the concept of information literacy among school librarians

- to examine their views on differences between information literacy and information technology literacy

- to identify their attitudes regarding the impact of school libraries on educational reforms

By investigating perceptions, views and attitudes, the results also serve as an indicator of the future infrastructural position of libraries in the information society. Data was gathered through a questionnaire, which combined open and close-ended questions. It was conducted over a four-week period in January-February 2006. Because of the modest timeline the coverage of the population of school librarians was not exhaustive $(\mathrm{N}=58)$ but reveals the main problems of positioning information literacy into the educational landscape.

\section{Results}

The statistical analysis of the demographic characteristics of the respondents showed that the majority of them belong to the younger generation with an average of 9.8 years of work experience. They mostly work in primary schools $(71 \%$; $N=41)$, in different Croatian counties. The great majority of libraries the respondents work in are staffed with one librarian $(96 \%$; $=54)$. The responses surfaced several critical aspects regarding information literacy in the school environment: only $67 \%(\mathrm{~N}=39)$ of libraries offer user education on a regular basis, while only $24 \%(\mathrm{~N}=14)$ of them have documented and published their user education program. When it comes to information literacy as an integral part of user education, the number further declines to $18 \%(\mathrm{~N}=10)$.



Table 1: Libraries with integrated information literacy program

The study also tried to determine what types of educational activities are libraries at Croatian schools performing. The responses where distributed among following categories:

- using information resources (encyclopaedias, catalogues....)

- locating books in libraries

- using the reference collection 
- computer literacy, using computers

- user behaviour in libraries

- borrowing books.

Important dimensions of success in the information literacy agenda are forms of cooperation with the teaching staff and the support of the school environments in general. The results have shown that only $18 \%$ of the school librarians cooperate with teachers when educating pupils, while only $16 \%$ of them think they are encouraged for educational activities by their environment.

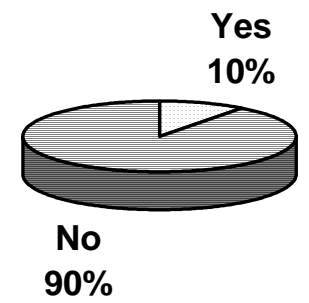

Table 2: User education stimulated by the environment

Having in mind the absence of information literacy and predominance of computer literacy in educational policies and strategies, perceptions among librarians regarding these two concepts where investigated. The majority of surveyed librarians $(86 \%)$ stated that they where familiar with the concept of computer literacy and defined it in similar ways, as the use of computers, the hardware, software and the Internet. When it comes to information literacy the respondents indicated that the rate of understanding the concept is considerably lower. Only $50 \%$ of the respondents claimed that they are familiar with information literacy and are able to define it correctly or relative correctly, which is a considerably lower percent compared computer literacy. It was interesting to find out that several respondents defined information literacy as some kind of "advanced use of information and communication technologies", or even understand these two as similar concepts.

The surveyed librarians where also asked to determine whether they think that teachers differ computer and information literacy. The results show that $67 \%$ of the librarians think teachers are familiar with computer literacy, but that only $10 \%$ among them believes teachers understand the concept of information literacy. Results regarding the opinions of librarians about the recognized role of libraries as an agent for educational reforms are also alarming. Only $5 \%$ of the respondents believe the educational system has recognized the role of libraries in school reforms. 


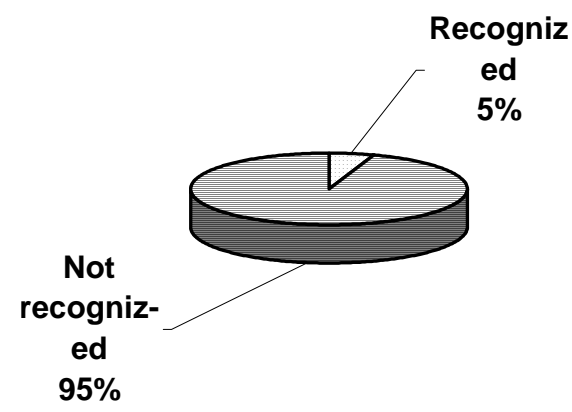

Table 3: Position of school librarians in educational reforms

The last open-ended question referred to the greatest challenges that will influence the future work of librarians. The majority of librarians stated that the lack of equipment, insufficient financing and technology represent important challenges, while aspects crucial for information literacy like the educational role or cooperation with teachers acquired lower response rates.



\section{Discussion}

The survey surfaced several intriguing results, fostering the need to create a clear understanding of the concept of information literacy. According to the responses, user education in general is still a peripheral rather then a central concern for school libraries in Croatia. Educational activities are not regularly formalized or manifested in published documents while information literacy is rarely integrated into programs. The absence of information literacy and user education programs in school libraries is partly caused by the stated low cooperation rates with teachers and the general lack of support from the school environment when it comes to educational activities in libraries. 
Responses regarding the content of educational activities shows that the majority of libraries carries out only basic forms of introduction to the library and information resources, although a focus on knowledge construction and human understanding, the development and utilization of knowledge and skills that are comprised in the concept of information literacy are essential ingredients in implementing educational reforms and improving student learning.

This survey revealed a general misunderstanding of the concept of information literacy, urging for clarification and reconceptualization of views among librarians, teachers and generally the context of primary and secondary education. Compared to the concept of information technology or computer literacy, school librarians in Croatia are far less familiar with information literacy. When trying to propose a definition of the term information literacy, they either associate it with finding and retrieving information, or they determine it as a way of retrieving information in digital format, Internet retrieval et.c. As opposed to the expressed definitions, information literacy is a much broader concept which goes beyond access, retrieval or familiarity with information resources and includes evaluation, organization, critical thinking and use. It incorporates attitudes, values and perspectives that allow individuals to function in an information rich environment and supports constructivist approaches that encourage students to take control of their own learning. The unfavorable current state captured in this snapshot investigation is rooted in the wider information and educational policy conducted in Croatia. A consequence of the missing nationwide information literacy policy is the lacking support of the teaching staff in these endeavours. Therefore initiatives in information literacy are almost exclusively left to the librarians alone, who are overburdened and do not have time to cope with the demanding tasks of planning and conducting training courses in information literacy.

\section{Conclusion}

The real challenge for the future of learning and teaching in primary, secondary and terciary education will be how to develop and utilize knowledge and skills or investigative methods to identify, access, retrieve and apply relevant content. A crucial pillar for developing these capabilities is information literacy, which represents a a whole conglomerate of values, attitudes, skills, knowledge and perspectives directed towards enabling for critical thinking, self-directed learning and the responsible cosnsume of information, each of one necessary for intelligent existence in the information age. Although the recognition that learning how to learn is fundamental to economic and personal success is rooted in information and educational policies worldwide, information literacy as an important component of this premise currently carries no weight in the eyes of the Croatian school system.

This paper reports on findings from a survey that was conducted to elicit perceptions of information literacy among librarians for whom information literacy should be a pervasive concern. The investigation showed that too many librarians still don't understand or implement information literacy and sometimes confuse it with information technology literacy. A similar qualification is visible in Croatia's wider 
information policy context, which is concentrated on providing equipment and infrastructure, neglecting the question if citizens will have necessary capabilities to make beneficial use of those investments.

The identified marginalization is the nucleus of the information literacy problem: librarians can prepare and offer high quality information literacy programs, they will not be used and will remain on the margins of society if information literacy carries little weight in the eyes of the educational system, the labour market or the social context. This constellation leads to the recommendation of a top-down approach in the form of declared information literacy policy statements on a national and international level that will recognize IL as a developmental resource. It is also necessary to undertake additional efforts to promote the information literacy philosophy among librarians as well as the population of teachers. A shared understanding of information literacy among those professions and policy makers, school administration, terciary education and employers is crucial, since without synergized actions between these groups neither reform processes, aspirations towards excellence in education nor a information literate society cannot be accomplished.

\section{References}

Bawden, D. (2001). Information and digital literacies: a review of concepts. Journal of documentation, 57, 2, 218-59.

Breivik P.S. (1999) . Take II - information literacy: revolution in education. Reference Services Review, 27, $3,271-276$.

Bruce, C. (2002). Information literacy as a catalyst for educational change: a background paper. White Paper prepared for UNESCO, the U.S. National Commission on Libraries and Information Science, and the National Forum on Information Literacy, for use at the Information Literacy Meeting of Experts, Prague, The Czech Republic. Retrieved January, 2006, from http://www.nclis.gov/libinter/infolitconf\&meet/papers/bruce-fullpaper.pdf

Guide through the Croatian National Educational Standards for Primary schools. (2005). Retrieved January, 2006, from http://www.mzos.hr/datoteke/hnos/cnes.pdf

The Prague declaration "Towards an information literate society" (2003). Retrieved February, 2006, from: http://www.nclis.gov/libinter/infolitconf\&meet/postinfolitconf\&meet/PragueDeclaration.pdf

Špiranec, S. (2003). Information literacy: key to lifelong learning <In Croatian>. Edupoint, 3, 17. Retrieved February, 2006, from: http://www.carnet.hr/casopis/17/clanci/1

Todd, R. (2001). Transitions for preferred futures of school libraries: Knowledge space, not information place, Connections, not collections, Actions, not positions Evidence, not advocacy. Paper presented at the $30^{\text {th }}$ Annual conference of the International Association of School Librarianship, Auckland, New Zealand. Retrieved March, 2006, from http://www.iaslslo.org/virtualpaper2001.html 


\section{Biographical Notes}

Jadranka Lasic-Lazic is a Professor of Information Science and the Head of Information Science Department at the University of Zagreb. She is also the former head of a public library in Zagreb and has fifteen years of teaching experience in the field of information and library science. She is the author of several researches and publications on information infastructure, knowledge organization, science classification, general and technological education of librarians and information professionals.

Sonja Špiranec, M.Sc., is a research and teaching assistant at the Department of Information Sciences in Zagreb. For several years she was a a librarian at the Croatian National- and University library where she was actively involved in creating an user education program and information literacy tutorial.

Mihaela Banek Zorica is a PhD student and research and teaching assistant at the Department of Information Sciences in Zagreb. She published a book on school libraries and several journal and conference papers. Main interest areas are knowledge organization, information retrieval, school libraries and education. 
Reproduced with permission of the copyright owner. Further reproduction prohibited without permission. 